\title{
Teaching A Course on Corruption and Informality in Russia: An International Experience ${ }^{1}$
}

\author{
E. DENISOVA-SCHMIDT*, L. NICOLAS-KRYZHKO ${ }^{2 * *}$
}

\begin{abstract}
*Elena Denisova-Schmidt - DSc in Philosophy, MBA, Research Associate, University of St. Gallen (Switzerland); Research Fellow, Boston College Center for International Higher Education (USA). Address: University of St. Gallen, Gatterstr, 3, 9010 St. Gallen, Switzerland. E-mail: elena.denisova-schmidt@unisg.ch

**Lena Nicolas-Kryzhko - DSc in Philosophy, Mobility Division, Siemens AG (Germany). Address: Siemens AG, Nuernberger Str. 74, 91052 Erlangen, Germany. E-mail: lena.nicolas-kryzhko@siemens.com

Citation: Denisova-Schmidt E., Nicolas-Kryzhko L. (2018) Teaching A Course on Corruption and Informality in Russia: An International Experience. Mir Rossii, vol. 27, no 4, pp. 129-140. DOI: 10.17323/1811-038X-2018-27-4-129-140
\end{abstract}

Corruption has been broadly discussed in the academic literature for several decades, yet there are few studies dedicated to addressing this topic in the classroom. This paper aims to fill this research gap by providing an example of a seminar on corruption and informal practices in Russia, given for international students at one Western European university. The aim of the seminar was to study the phenomenon of corruption from different perspectives, using different teaching techniques and materials, in order to encourage students to conduct their own analyses and reflections on real-life situations. Drawing on the structure of the seminar, this article provides a brief overview of the historical perspective of corruption in Russia, then summarizes the approach and teaching methods used in the seminar, including presentations, group work, discussions and homework. Finally, the authors provide a detailed overview of the learning materials used. They conclude that an interdisciplinary approach involving numerous literary works, films and case studies is particularly suitable for understanding the concept of "corruption" and "informality" in their respective cultural contexts and for preparing students to face this issue in their (future) professional lives.

Key words: Corruption, informality, Russia, executive education, interdisciplinary studies

1 This is a significantly revised and updated version of [Denisova-Schmidt, Kryzhko 2018].

2 The views expressed in this article are Dr. Nicolas-Kryzhko's own and do not represent those of her employer. 


\section{Introduction}

There are not many studies on how to teach such sensitive topics as corruption [Wolf, Graeff 2018], not because this topic is unimportant, but rather because of the complexity of such issues. The general research on corruption suggests that it might be considered a 'criminal act', a 'cultural norm', or a 'way to get things done' depending on various factors (see discussions in [Ledeneva 2009; Ledeneva 2013; Barsukova, Ledeneva 2014; Barsukova, 2009, 2013 and 2017; Denisova-Schmidt, Prytula 2017]). Corruption can be fully understood only within a particular national context; within the historical, political, and cultural preconditions that created the social structures in which it exists [DenisovaSchmidt, Prytula 2018; Ledeneva 2018].

On the basis of these theoretical considerations and of empirical observations, a seminar was conceived that takes such aspects into account. This seminar, titled "Corruption and Informal Practices in Russia: Past and Present"3, was developed to help students look at corruption from different perspectives. Over the course of twelve teaching units, students had the opportunity to learn about and analyze various forms of corruption in different media and from various disciplinary perspectives. The application of different teaching methods also enabled an in-depth reflection through, for example, reading texts, watching films, and creating presentations, as well as through extensive discussions and exchanges of opinions within the context of the group assignments. In addition, the seminar analyzed several case studies from international business, which were to prepare the students for their future professional activities. The discussion of these case studies was less about finding the "right" solution than about describing a range of different approaches and possible consequences, and exchanging the students' own experiences and ideas. The students' reflections show that an interdisciplinary approach involving numerous literary works, films, and practical examples is particularly suitable for explaining the concepts of "corruption" and "informality" in their respective cultural context.

\section{Historical Perspectives of Corruption in Russia}

Corruption has a long history and tradition in Russia. Ivan IV (Ivan the Terrible) was one of the first Russian leaders to have expressed concern about corruption in the country. He enacted his first anti-corruption measures with his 1550 code (sudebnik). This was mainly concerned with the bribery of officials, as the system worked in such a way that Russian officials were hired by the state but in fact paid by the population - the socalled "feeding system" (sistema kormleniya). The post of a civil servant was officially called a korm - literally a "food source". In addition to a basic salary, the officeholder received fees for certain services, gifts of gratitude and recognition, as well as gifts for bending the law. Especially in the last two categories, there was a great amount of leeway. Although some tsars, such as Peter I in 1715 and Catherine II in 1765, tried to change the system and raise the wages for officials, they failed in their reforms.

\footnotetext{
3 The seminar took place in spring 2012 and spring 2013; a shortened version is now integrated into the negotiating courses within executive education.
} 
The "feeding system" remained an important part of the organizational structure in Russia at least until the beginning of the 19th century [Schattenberg 2008].

The first anti-corruption laws after the October Revolution - the Decree of 8 May 1918 - also concerned bribery. What was new was the fact that persons who offered bribes or were otherwise involved in such transactions could also be punished. In general, the Soviet government scarcely used the term "corruption" on the grounds that this phenomenon had been part of the tsarist period and should be abolished with the new system. In a secret letter from the Central Committee of the Communist Party of the Soviet Union (CPSU) dated 29 March 1962 it was argued, among other things, that bribery is a social phenomenon that could only arise in an exploitative society. In the Soviet Union, bribery was still common practice, but the reasons for it were the lack of effective educational work on the part of the Party, the trade unions and the state organs that needed to be made up.

One of the results of the ineffective Soviet planned economy was that the supply of goods and services could not cover the ever-growing demand. This is how blat ${ }^{4}$ emerged: the use of relationships to acquire goods and services under adverse conditions and to solve problems bypassing the formal rules [Ledeneva 1998]. What did this look like in everyday life? Simis [Simis 1982, pp. 146-174] shows a to-do list of his Soviet friend (Table 1), a lawyer, which shows that food, leisure activities and even toilet paper could hardly be procured on one's own - i.e., without resorting to blat.

\section{Table 1. Weekly routine in the 1980 s*}

\begin{tabular}{|l|l|}
\hline What? & Who? \\
\hline Food & Lyubov Lasarevna \\
\hline Dry cleaning & Big Lyuda \\
\hline Toilet paper & Little Lyuda \\
\hline Book by Fyodor Dostoevsky & Olga Nikolaevna (pralines) \\
\hline Concert tickets & Irina Mikhailovna \\
\hline Flowers & Ivan Kirillovich (bottle) \\
\hline
\end{tabular}

*adapted from [Ledeneva 1998, p. 45].

Simis, like anyone who lived through this time, can interpret this list very easily: "pralines" and "bottle" mean that Olga Nikolaevna should receive a box of chocolates for the Fyodor Dostoevsky book, and that Ivan Kirillovich had to be given a bottle of alcohol for purchasing the flowers [Denisova-Schmidt (3) 2015]. The people listed in the second column without gifts, if they were not close friends or relatives, were often expected to receive some other consideration, which may involve the abuse of the power of an entrusted position, such as the sale of food only to selected persons or for a different (higher) price.

4 Swiss and other international students socialized in the West understood this concept very quickly when they compared it, for example, with the current situation in the apartment market in Zurich and Geneva: it is almost impossible to rent an apartment without using connections in these two cities. 
It was naïve to believe that all the practices that had arisen in the tsarist and Soviet eras, which shaped the social system in Russia for several centuries, would disappear quickly. As in the past, corruption is often judged negatively in the public discourse today. This assessment, however, changes dramatically when corruption helps to solve personal problems. This could, for example, involve an informal payment (a) to a hospital to provide treatment or care to a family member; or (b) to a kindergarten to secure a place for one's own child; or (c) to have a son declared "unfit" for military service [DenisovaSchmidt 2012; Denisova-Schmidt (2) 2015]. Just as in the past, there are also severe anticorruption laws today, which are applied rarely and selectively - and often to distract from internal problems and reforms that have not been completed in certain areas.

\section{Didactical Approaches}

The "Corruption and Informal Practices in Russia: Past and Present" seminar was offered at the University of St. Gallen (HSG) in the field of "Cultural Competence" at the master's level. The aim of the course was to enable students to understand the origin and development of corruption in Russia from a historical and cultural perspective and to recognize and analyze the spread and possible consequences of this phenomenon for the country and its neighbors. In addition, students learned how to work in a traditionally corrupt country on the basis of general ethics.

In addition to the instructor's lectures, other teaching methods such as partner or group work and the analysis of case studies were used in the seminar. The assessment consisted of two parts: a written group assignment with a presentation $(70 \%)$ and an individual exam (open questions, 30\%). It was assessed with an overall score.

The terms "corruption" and "informal practices" were explained and analyzed in their historical, cultural, political, legal, social and economic embedding in Russia. Through the examples of case studies, feature and documentary films, literary works and documents, both concepts were explained and expanded.

The group of approximately 40 students arranged themselves into 10 working groups and selected topics for presentations ${ }^{5}$ on the intranet. The first 45 minutes of each class were reserved for the working group presentations: 30 minutes of lecture and 15 minutes of discussion with their fellow students. In the last 45 minutes, some aspects of the presentations were commented on and expanded, and other forms of cooperation were suggested. The structure of the seminar is described below, including the topics of the teaching units, the presentations and (homework) assignments for all participants. Table 2 shows the exact structure of the seminar.

Talking in class about sensitive issues involving self-reflection was a very productive and efficient tool. Students learn to recognize that corruption might exist everywhere, differing only in its forms, frequency, visibility and acceptance in a society or - depending on the context - a professional community. Many, especially male, students were shocked by the tough conditions in the Russian army, for example, and could understand why young Russian men try to avoid military service.

\footnotetext{
5 The subjects of the seminar were formulated very precisely, especially for the historical aspects (No. 2, No. 3, No. 4), as well as the depiction of corruption and informal practices in feature films (No. 5).
} 


\section{Summary}

The current paradigm of corruption research is based on three assumptions: that corruption can be defined, that it can be quantified and that appropriate anti-corruption measures can be derived. This is not the case in post-communist countries, however, as in these countries the boundaries between the "public" and the "private", between legal, socially acceptable norms and illegal, corrupt norms are imprecise. As a result, the anti-corruption measures used thus far have only had limited effectiveness or even a contrary effect. Corruption can be not only a "deviation from the norm" but also a "norm" and, above all, an "effective instrument", especially in an institutionally weak environment. In the training of young managers and executives, one should consider this and examine corruption from different perspectives. In this way, young people, specialists and executives can be better prepared for successful international assignments. They are better able to negotiate the balancing act between Western norms and the rules of the corresponding market in post-communist countries, and to act ethically.

\section{Table 2. Structure of the Seminar}

\begin{tabular}{|l|l|}
\hline 1. & Introduction \\
\hline 2. & $\begin{array}{l}\text { Corruption and Informal Practices (IP) in the Tsarist era } \\
\text { Presentation: Based on Nikolai Gogol's book "Revisor" [Gogol 1836] }{ }^{6} \text { and one of the films of the novel, } \\
\text { "The Inspector General" [Koster 1949]. } \\
\text { Everyone: Homework: Read an excerpt from Schattenberg [Schattenberg 2008, pp. 23-27], which } \\
\text { provides a short overview of working assignments and career development as an official living in Tsarist } \\
\text { Russia. } \\
\text { Group work in the classroom: Imagine you live in the 19th century and would like to inspire your good } \\
\text { friend to work as an official. Formulate reasons to convince him/her. Point out possible risks. }\end{array}$ \\
\hline $\mathbf{3 .}$ & $\begin{array}{l}\text { Corruption and IP in the USSR } \\
\text { Presentation: Based on the film "The Honor of the Godfather - Russia's Mafia" [Gentelev 2010] and the } \\
\text { book by Ledeneva [Ledeneva 1998]. } \\
\text { Everyone: Group work in class: } \\
\text { Is there something similar to blat in your home countries? If so, how does it work? } \\
\text { What can be achieved through blat in your home countries and what cannot? }\end{array}$ \\
\hline 4. & $\begin{array}{l}\text { Corruption and IP in Literature } \\
\text { Presentation: Based on the book by Tregubova [Tregubova 2006]. } \\
\text { Everyone: Homework: Read an extract from Earley [Earley 2007, pp. 25-30, 38-43], illustrating career } \\
\text { development among the elites in the Soviet Union. }\end{array}$ \\
\hline $\mathbf{5 .}$ & $\begin{array}{l}\text { Corruption and IP in Films } \\
\text { Presentation: }{ }^{7} \text { Based on the films "12" [Michalkov 2007] and "Ital'yanets" [Kravchuk 2005]. }\end{array}$ \\
\hline
\end{tabular}

6 "Revisor" was recently staged by the Theater Kanton Zürich (during the 2017-2018 season). It was slightly adapted to the current climate, so for example, the mayor was dreaming about moving to Moscow and taking a position as CEO of a large oil company. The main change, however, was that the title role was played by a woman - not Mr. Khlestakov but Mrs. Khlestakova - probably to indicate that there are no gender-based differences in attitudes towards corruption.

7 Further recommendations:

Film "Le concert" (Radu Mihaileanu, 2009 // http://www.imdb.com/title/tt1320082/).

Film "Elena" (Andrey Zvyagintsev, 2011 // http://www.imdb.com/title/tt1925421/).

Film "Leviafan” (Andrey Zvyagintsev, 2014 // http://www.imdb.com/title/tt2802154/). 


\begin{tabular}{|c|c|}
\hline 6. & $\begin{array}{l}\text { Corruption and IP today: Politics } \\
\text { Presentation: none } \\
\text { Everyone: Read two texts: [Illarionov 2009] and the "Pussy Riot" case. } \\
\text { Imagine you are working for a company that is planning to open a branch in Russia. You and your } \\
\text { colleagues are responsible for the project in Russia. How would you take the political factors involved in } \\
\text { site analysis into account? }\end{array}$ \\
\hline 7. & $\begin{array}{l}\text { Corruption and IP today: Education } \\
\text { Presentation: None } \\
\text { Everyone: [Klein 2010] }{ }^{8} \text {. } \\
\text { Group work in the classroom: You are hiring new employees and making introductions. You have doubts } \\
\text { about whether the following documents are "real". What do you do? How do you verify this? } \\
\text { a. You have doubts about a diploma and training certificate; } \\
\text { b. You have doubts about a driver's license (for this job, a company car is provided); and } \\
\text { c. You have doubts about a medical certificate. }\end{array}$ \\
\hline 8. & $\begin{array}{l}\text { Corruption and IP today: Army and Police } \\
\text { Presentation: None } \\
\text { Everyone: (Homework): Read an excerpt from Politkovskaya [Politkovskaya 2005, pp. 12, 15, 32-43], } \\
\text { which describes the tough living and serving conditions in the Russian Army. } \\
\text { Group work in class: } \\
\text { Do you know forms similar to Dedovshchina }{ }^{9} \text { in your homelands? What does this practice involve and } \\
\text { how is it judged? } \\
\text { Imagine you are Russian and you have to do your military service. What would you do? } \\
\text { (Alternative): What would you recommend to a Russian friend? }\end{array}$ \\
\hline 9. & $\begin{array}{l}\text { Corruption and IP today } \\
\text { Presentation: Selective application of the laws per the example of Sergei Magnitsky and Mikhail } \\
\text { Khodorkovsky. } \\
\text { Everyone: Discussion of the text by Ledeneva [Ledeneva 2011]. }\end{array}$ \\
\hline 10. & $\begin{array}{l}\text { Corruption and IP from the perspective of Russian companies } \\
\text { Presentation: None } \\
\text { Everyone: Discussion of a case study [Denisova-Schmidt (2) 2011], based on a real story of compliance } \\
\text { within one Russian company: the company is challenged to comply with a quota on hiring disabled people, } \\
\text { not because they do not want to support people, but rather by their technical unpreparedness to do so, so } \\
\text { they are forced to find 'creative solutions' to avoid this quota. }\end{array}$ \\
\hline 11. & $\begin{array}{l}\text { Corruption and IP today from the perspective of foreign companies } \\
\text { Presentation: Based on [Ledeneva, Shekshnia } 2011]^{10} \text {, who show how to manage non-compliance practices } \\
\text { in endemically corrupt environments } \\
\text { Everyone: Exercises [Denisova-Schmidt, Kryzhko 2018]. }\end{array}$ \\
\hline 12. & Reflection \\
\hline
\end{tabular}

8 Further recommendations:

Film "Le concert" (Radu Mihaileanu, 2009 // http://www.imdb.com/title/tt1320082/).

Film "Elena" (Andrey Zvyagintsev, $2011 / /$ http://www.imdb.com/title/tt1925421/).

Film "Leviafan" (Andrey Zvyagintsev, 2014 // http://www.imdb.com/title/tt2802154/).

9 Further recommendations:

Denisova-Schmidt E., Huber M., Leontyeva E. (2) (2016) On the Development of Students Attitudes towards Corruption and Cheating in Russian Universities. European Journal of Higher Education, vol. 6, no 2, pp. 128-143. DOI: 10.1080/21568235.2016.1154477; Denisova-Schmidt E. (1) (2015) Academic Dishonesty or Corrupt Values: the Case of Russia. EU: ANTICORRP, March 25, 2015. Available at: http://anticorrp.eu/publications/academic-dishonestyor-corrupt-values-the-case-of-russia/, accessed 20.07.2018; Denisova-Schmidt E. (2013) Justification of Academic Corruption at Russian Universities: A Student Perspective, Harvard University: Edmond J. Safra Working Papers No. 30. Available at: http://ssrn.com/abstract=2353513, accessed 20.07.2018; Klein E. (2017) Bildungskorruption in Russland und der Ukraine, Stuttgart: Ibidem-Verlag.

10 Dedovshchina is the "rule of the elders" - "Physical and psychological violence against recruits, one of the most serious problems in the Soviet [and later Russian] army" [Denisova-Schmidt (1) 2015].

11 Further recommendations: Shekshnia, S., Ledeneva, A. and Denisova-Schmidt, E. Managing Business Corruption: Targeting Non-Compliant Practices in Systematically Corrupt Environments. Slavonic and East European Review, 95, 1, 2017, pp. 151-174. 


\section{References}

Barsukova S. (2009) Corruption. Academic Debates and Russian Reality. Russian Politics and Law, no 4, pp. 8-27.

Barsukova S. (2013) Mutations du Capitalism et Institutionnalisation de la Corruption dans la Russie Contemporaine. Revie Internationale de Politique Comparee, vol. 20, no 3, pp. 41-63.

Barsukova S. (2017) Esse o neformal'noj ekonomike, ili 16 ottenkov serogo [Essays on Informal Economy, or Sixteen Shades of Grey], Moscow: HSE.

Barsukova S., Ledeneva A. (2014) Ot global'noj korruptsionnoj paradigmy k izucheniyu neformal'nykh praktik: razlichiya $\mathrm{v}$ podkhodakh autsajderov i insajderov [From Global Corruption Paradigm to the Study of Informal Practices: Outsiders vs Insiders]. Voprosy ekonomiki, no 2, pp. 118-132.

Denisova-Schmidt E. (2010) Korruption und informelle Praktiken im russischen Geschäftsleben: Fallbeispiele aus der Sicht ausländischer Unternehmer. Russland-Analysen, no 210, pp. 8-19.

Denisova-Schmidt E. (1) (2011) Geschäftspartner Russland. Erfahrungen mit einem europäischen Land der besonderen Art. Schweiz und Europa - Auswirkungen auf Wirtschaft, Recht und Gesellschaft. 6 (eds. Tanner A.-C., Siebeneck C., Brändli B.). Band der Schriftenreihe der Assistierenden der Universität St. Gallen (HSG), Bern: Stämpfli Verlag, pp. 165-172.

Denisova-Schmidt E. (2) (2011) Quota for the Employment of Disabled People in Russia: Strategies for Compliance. Emerald Emerging Markets Case Studies Collection, vol. 1, no 4 , pp. 1-10.

Denisova-Schmidt E. (2012) Corruption and Informal Practices in Russia. Euxeinos. Online Journal of the Center for Governance and Culture in Europe, no 7, pp. 3-19. Available at: http://www.gce.unisg.ch/en/Euxeinos.aspx, accessed 20.07.2018.

Denisova-Schmidt E. (2013) Justification of Academic Corruption at Russian Universities: A Student Perspective, Harvard University.

Denisova-Schmidt E. (2014) Institutional Performance and Social Values in Russia. EU: ANTICORRP,June2014.Availableat:https://www.researchgate.net/publication/301788939 INSTITUTIONAL_PERFORMANCE_AND_SOCIAL_VALUES_IN_RUSSIA, accesse $\bar{d}$ 20.07.2018.

Denisova-Schmidt E. (1) (2015) Academic Dishonesty or Corrupt Values: the Case of Russia. EU: ANTICORRP, March 25, 2015. Available at: http://anticorrp.eu/publications/academicdishonesty-or-corrupt-values-the-case-of-russia/, accessed 20.07.2018.

Denisova-Schmidt E. (2) (2015) Doublethink, Russian Style. EU: ANTICORRP, January 22, 2015. Available at: http://anticorrp.eu/news/doublethink-russian-style/, accessed 20.07.2018.

Denisova-Schmidt E. (3) (2015) Russlanddeutsche. Geschichte und Gegenwart. Zeitzeugen erzählen über Heimat, Migration und Engagement, Stuttgart: Ibidem Verlag.

Denisova-Schmidt E., Huber M., Prytula Y. (2015) An Experimental Evaluation of an AntiCorruption Intervention among Ukrainian University Students. Eurasian Geography and Economics, vol. 56, no 6, pp. 713-734.

Denisova-Schmidt E., Huber M., Leontyeva E. (1) (2016) Okazyvayut li antikorruptsionnye prosvetitel'skie kampanii vliyanie na studentov? Po rezul'tatam issledovanij v Rossii i Ukraine [Do Anti-Corruption Educational Campaigns Reach Students? Some Evidence from Russia and Ukraine]. Voprosy obrazovaniya, no 1, pp. 61-83. Available at: https://vo.hse.ru/data/2016/03/21/1128183424/Denisova.pdf, accessed 20.07.2018.

Denisova-Schmidt E., Huber M., Leontyeva E. (2) (2016) On the Development of Students Attitudes towards Corruption and Cheating in Russian Universities. European Journal of Higher Education, vol. 6, no 2, pp. 128-143. DOI: 10.1080/21568235.2016.1154477

Denisova-Schmidt E., Huber M., Prytula Y. (3) (2016) Corruption among Ukrainian Businesses: Do Firm Size, Industry and Region Matter? State Capture, Political Risks and International Business. Cases from the Black Sea Region (eds. Leitner J., Meissner H.), London, New York: Routledge, pp. 108-119. 
Denisova-Schmidt E., Kryzhko O. (2015) Managing Informal Business Practices in Russia: The Experience of Foreign Companies. Mir Rossii, vol. 24, no 4, pp. 149-174.

Denisova-Schmidt E., Kryzhko O. (2018) Weiterbildung zum Umgang mit Korruption in Russland. Korruptionsbekämpfung vermitteln (eds. Wolf S., Graeff P.), Springer VS: Wiesbaden, pp. 69-288.

Denisova-Schmidt E., Prytula Y. (2017) Perceived Corruption and Trust among Ukrainian Firms. Eastern European Economics, vol. 55, no 4, pp. 324-341.

Denisova-Schmidt E., Prytula Y. (2018) Corruption in Doing Business in Ukraine: A Way to Get Things Done? Business Horizons (forthcoming).

Earley P. (2007) Comrade J. The Untold Secrets of Russia's Master Spy in America after the End of the Cold War, New York: G.P. Putnam's Sons.

Gentelev A. (film director) (2010) The Honor of the Godfather - Russia's Mafia, Finland, Germany, Israel, Norway, Spain, Sweden, Switzerland, Poland.

Gogol N. (1836) Der Revisor. Komödie in fünf Akten (ed. and trans. Zelinsky B.).

Illarionov A. (2009) The Siloviki in Charge. Journal of Democracy, vol. 20, no 2, pp. 69-72.

Klein E. (2010) Korruption im russischen Bildungswesen. Russland-Analysen, no 210, pp. 2-7.

Klein E. (2017) Bildungskorruption in Russland und der Ukraine, Stuttgart: Ibidem-Verlag.

Koster H. (film director) (1949) The Inspector General, USA: Warner Brothers.

Kravchuk A. (film director) (2005) Ital'yanets, Russia: Lenfilm.

Ledeneva A. (1998) Russia's Economy of Favours: Blat, Networking, and Informal Exchange, Cambridge, New York: Cambridge University Press.

Ledeneva A. (2009) Corruption in Postcommunist Societies in Europe: a Re-examination. Perspectives on European Politics and Society, vol. 10, no 1, pp. 69-86.

Ledeneva A. (2011) Telephone Justice in Russia. EU-Russia Centre Newsletter, XVIII.

Ledeneva A. (2013) A Critique of the Global Corruption 'Paradigm'. Postcommunism from Within: Social Justice, Mobilization, and Hegemony (eds. Kubik J., Linch A.), New York: NYU Press, pp. 296-332.

Ledeneva A. (ed.) (2018) The Global Encyclopaedia of Informality. Volumes 1-2, London: UCL Press.

Ledeneva A., Shekshnia S. (2011) Doing Business in Russia: Informal Practices and Anti-Corruption Strategies. Russie.Nei.Visions, no 58, March 2011. Available at: https://www.ifri.org/en/publications/enotes/russieneivisions/doing-business-russiainformal-practices-and-anti-corruption, accessed 20.07.2018.

Michalkov N. (film director) (2007) 12, Russia: Tri T.

Mihaileanu R. (film director ) (2009) Le Concert, France, Italy, Romania, Belgium, \& Russia: Oï Oï Ö̈ Productions, Les Productions du Trésor, \& France 3 Cinéma et al. Available at: https://www.imdb.com/title/tt1320082/, accessed 20.07.2018.

Politkovskaya A. (2005) In Putins Russland, Bonn: Bundeszentrale für politische Bildung.

Schattenberg S. (2008) Die korrupte Provinz? Russische Beamte im 19. Jahrhundert, Frankfurt, New York: Campus Verlag.

Simis K. M. (1982) USSR - the Corrupt Society: The Secret World of Soviet Capitalism, New York: Simon and Schuster.

Tregubowa E. (2006) Die Mutanten des Kreml: Mein Leben in Putins Reich, Berlin: Tropen Verlag.

Wolf S., Graeff P. (eds.) (2018) Korruptionsbekämpfung vermitteln, Springer VS: Wiesbaden. 


\title{
Преподавание курсов на тему коррупции и неформальности в России: международный опыт
}

\author{
Е. ДЕНИСОВА-ШМИДТ*, Л. НИКОЛЯ-КРЫЖКО**
}

\begin{abstract}
*Елена Денисова-Шмидт - доктор философских наук, научный сотрудник, Университет Санкт-Галлена, Швейцария; Центр по изучению международного высшего образования при Бостонском колледже, США. Адрес: University of St. Gallen, Gatterstr, 3, 9010 St. Gallen, Switzerland. E-mail: elena.denisova-schmidt@unisg.ch

**Лена Николя-Крыжко - доктор философских наук, руководитель отдела по работе с деловыми партнерами, Сервисное обслуживание клиентов департамента «Мобильность», Сименс. Адрес: Siemens AG, Nuernberger Str. 74, 91052 Erlangen, Germany. E-mail: lena.nicolas-kryzhko@siemens.com
\end{abstract}

Цитирование: Denisova-Schmidt E., Nicolas-Kryzhko L. (2018) Teaching A Course on Corruption and Informality in Russia: An International Experience. Mir Rossii, vol. 27, no 4, pp. 129-140. DOI: 10.17323/1811-038X-2018-27-4-129-140

Изучению явления коррупции в рамках образовательного процесса в высшей школе до сих пор уделялось недостаточное внимание. Это связано с необычайной сложностью данного явления, которое можно трактовать и как «преступление», и как «культурную особенность» в зависимости от обстоятельств, а также исторических, социальных и культурных факторов определенной среды. Таким образом, изучать явление коррупции возможно лишь в разрезе исторических, политических и культурных факторов, которые обусловили появление коррупции в данном контексте. На основе этих принципов был разработан семинар под названием «Коррупция и неформальные практики в России: прошлое и будущее». Этот семинар объединил различные подходы к изучению коррупции, а также интенсивное обсуждение предложенных литературных произведений, фильмов и реальных примеров из жизни. Таким образом, студенты были вовлечены в процесс активного анализа коррупционных ситуаций, самостоятельного поиска возможных решений и обсуждения их последствий. Позитивные отзывы участников семинара свидетельствуют об успехе данного подхода.

Коррупция в России имеет долгую историю. Еще Иван Грозный обратил внимание на это явление в Судебнике 1550 г., предусмотрев первые антикоррупционные меры. Позже Петр I и Екатерина II также проводили ряд реформ по борьбе с коррупцией, но система «кормления» породила злоупотребления и произвол местных властей, и такая практика глубоко укоренилась в российском обществе. Советская власть рассматривала коррупцию как «пережиток» царской власти, но тем не менее в одном из первых декретов от 8 мая 1918 г. упоминались и осуждались взятки. Однако и в XX веке мероприятия по борьбе с коррупцией не увенчались успехом: взятки, хоть и в другой форме, по-прежнему существовали. К тому же появилось и утвердилось такое явление, как «блат» - возможность получать дефицитные товары и услуги, используя знакомства и связи. Все это, безусловно, влияет и на сегодняшнюю ситуацию в стране, где то, что называется коррупцией в западной терминологии, часто является единственным способом решения проблемы и не считается чем-то предосудительным. 
Семинар «Коррупция и неформальные практики в России: прошлое и будущее» проводился в Университете Санкт-Галлена (Швейцария) для студентов-магистрантов в рамках программы по обучению культурной компетентности. В семинаре приняли участие около 40 студентов, работавших над выбранными темами в 10 группах. В первой половине занятия (45 минут) каждая из групп имела возможность представить свою тему и обсудить ее с другими студентами. Вторая половина отводилась на совместные обсуждения презентации, а также расширение темы и дополнение ее другими примерами. В семинаре использовались отрывки из художественной литературы, некоторые фильмы, научные пособия, законы, материалы международных организаций по борьбе с коррупцией, а также примеры из практики ведения бизнеса и повседневной жизни. В конце семинара проводился экзамен, состоявший на $70 \%$ из групповой работы по подготовке презентации (сама презентация и небольшая курсовая) и на $30 \%$ - из индивидуального письменного экзамена.

Этот семинар дал возможность студентам изучить различные формы коррупции, понять и проанализировать ее истоки, распространенность и принятие/неприятие в зависимости от контекста. Таким образом, студенты были подготовлены к возможным нестандартным ситуациям в международном бизнесе и к их решению на основе общепринятых норм и стандартов бизнес-этики.

Ключевые слова: коррупция, неформальность, Россия, образование для управляющих кадров, междисциплинарные исследования

\section{Литература}

Барсукова С.Ю. (2017) Эссе о неформальной экономике, или 16 оттенков серого. М.: ВШЭ. Барсукова С., Леденева А. (2014) От глобальной коррупционной парадигмы к изучению неформальных практик: различия в подходах аутсайдеров и инсайдеров // Вопросы экономики. № 2. С. 118-132.

Денисова-Шмидт Е., Хубер М., Леонтьева Е. (1) (2016) Оказывают ли антикоррупционные просветительские кампании влияние на студентов? По результатам исследований в России и Украине // Вопросы образования. № 1. С. 61-83 // https://vo.hse.ru/data/2016/03/21/1128183424/Denisova.pdf

Кравчук А. (режиссер) (2005) «Итальянец». Россия: Ленфильм.

Михалков Н. (режиссер) (2007) «12». Россия: Три Тэ.

Barsukova S. (2009) Corruption. Academic Debates and Russian Reality // Russian Politics and Law, no 4, pp. 8-27.

Barsukova S. (2013) Mutations du Capitalism et Institutionnalisation de la Corruption dans la Russie Contemporaine // Revie Internationale de Politique Comparee, vol. 20, no 3, pp. 41-63.

Denisova-Schmidt E. (2010) Korruption und informelle Praktiken im russischen Geschäftsleben: Fallbeispiele aus der Sicht ausländischer Unternehmer // Russland-Analysen, no 210, pp. 8-19.

Denisova-Schmidt E. (1) (2011) Geschäftspartner Russland. Erfahrungen mit einem europäischen Land der besonderen Art // Schweiz und Europa - Auswirkungen auf Wirtschaft, Recht und Gesellschaft. 6 (eds. Tanner A.-C., Siebeneck C., Brändli B.). Band der Schriftenreihe der Assistierenden der Universität St. Gallen (HSG), Bern: Stämpfli Verlag, pp. 165-172. 
Denisova-Schmidt E. (2) (2011) Quota for the Employment of Disabled People in Russia: Strategies for Compliance // Emerald Emerging Markets Case Studies Collection, vol. 1, no 4, pp. 1-10.

Denisova-Schmidt E. (2012) Corruption and Informal Practices in Russia // Euxeinos. Online Journal of the Center for Governance and Culture in Europe, no 7, pp. 3-19 // http://www.gce.unisg.ch/en/Euxeinos.aspx

Denisova-Schmidt E. (2013) Justification of Academic Corruption at Russian Universities: A Student Perspective, Harvard University.

Denisova-Schmidt E. (2014) Institutional Performance and Social Values in Russia // EU: ANTICORRP, June 2014 // https://www.researchgate.net/publication/301788939 INSTITUTIONAL PERFORMANCE AND SOCIAL_VALUES IN_RUSSIA

Denisova-Schmidt E. (1) (2015) Academic Dishonesty or Corrupt Values: the Case of Russia // EU: ANTICORRP, March 25, 2015 // http://anticorrp.eu/publications/ academic-dishonesty-or-corrupt-values-the-case-of-russia/

Denisova-Schmidt E. (2) (2015) Doublethink, Russian Style // EU: ANTICORRP, January 22, 2015 // http://anticorrp.eu/news/doublethink-russian-style/

Denisova-Schmidt E. (3) (2015) Russlanddeutsche. Geschichte und Gegenwart. Zeitzeugen erzählen über Heimat, Migration und Engagement, Stuttgart: Ibidem Verlag.

Denisova-Schmidt E., Huber M., Prytula Y. (2015) An Experimental Evaluation of an AntiCorruption Intervention among Ukrainian University Students // Eurasian Geography and Economics, vol. 56, no 6, pp. 713-734.

Denisova-Schmidt E., Huber M., Leontyeva E. (2) (2016) On the Development of Students Attitudes towards Corruption and Cheating in Russian Universities // European Journal of Higher Education, vol. 6, no 2, pp. 128-143. DOI: 10.1080/21568235.2016.1154477

Denisova-Schmidt E., Huber M., Prytula Y. (3) (2016) Corruption among Ukrainian Businesses: Do Firm Size, Industry and Region Matter? // State Capture, Political Risks and International Business. Cases from the Black Sea Region (eds. Leitner J., Meissner H.), London, New York: Routledge, pp. 108-119.

Denisova-Schmidt E., Kryzhko O. (2015) Managing Informal Business Practices in Russia: The Experience of Foreign Companies // Mir Rossii, vol. 24, no 4, pp. 149-174.

Denisova-Schmidt E., Kryzhko O. (2018) Weiterbildung zum Umgang mit Korruption in Russland // Korruptionsbekämpfung vermitteln (eds. Wolf S., Graeff P.), Springer VS: Wiesbaden, pp. 69-288.

Denisova-Schmidt E., Prytula Y. (2017) Perceived Corruption and Trust among Ukrainian Firms // Eastern European Economics, vol. 55, no 4, pp. 324-341.

Denisova-Schmidt E., Prytula Y. (2018) Corruption in Doing Business in Ukraine: A Way to Get Things Done? // Business Horizons (forthcoming).

Earley P. (2007) Comrade J. The Untold Secrets of Russia's Master Spy in America after the End of the Cold War, New York: G.P. Putnam's Sons.

Gentelev A. (film director) (2010) The Honor of the Godfather - Russia's Mafia, Finland, Germany, Israel, Norway, Spain, Sweden, Switzerland, Poland.

Gogol N. (1836) Der Revisor. Komödie in fünf Akten (ed. and trans. Zelinsky B.).

Illarionov A. (2009) The Siloviki in Charge // Journal of Democracy, vol. 20, no 2, pp. 69-72.

Klein E. (2010) Korruption im russischen Bildungswesen // Russland-Analysen, no 210, pp. 2-7.

Klein E. (2017) Bildungskorruption in Russland und der Ukraine, Stuttgart: Ibidem-Verlag.

Koster H. (film director) (1949) The Inspector General, USA: Warner Brothers.

Ledeneva A. (1998) Russia's Economy of Favours: Blat, Networking, and Informal Exchange, Cambridge, New York: Cambridge University Press.

Ledeneva A. (2009) Corruption in Postcommunist Societies in Europe: a Re-examination // Perspectives on European Politics and Society, vol. 10, no 1, pp. 69-86.

Ledeneva A. (2011) Telephone Justice in Russia // EU-Russia Centre Newsletter, XVIII.

Ledeneva A. (2013) A Critique of the Global Corruption 'Paradigm' // Postcommunism from Within: Social Justice, Mobilization, and Hegemony (eds. Kubik J., Linch A.), New York: NYU Press, pp. 296-332.

Ledeneva A. (ed.) (2018) The Global Encyclopaedia of Informality. Volumes 1-2, London: UCL Press. 
LedenevaA., Shekshnia S. (2011)Doing Business in Russia: Informal Practices andAnti-Corruption Strategies // Russie.Nei.Visions, no 58, March 2011 // https:/www.ifri.org/en/publications/ enotes/russieneivisions/doing-business-russia-informal-practices-and-anti-corruption

Mihaileanu R. (film director ) (2009) Le concert, France, Italy, Romania, Belgium, \& Russia: Oï Oï Oï Productions, Les Productions du Trésor, \& France 3 Cinéma et al. // https://www.imdb.com/title/tt1320082/

Politkovskaya A. (2005) In Putins Russland, Bonn: Bundeszentrale für politische Bildung.

Schattenberg S. (2008) Die korrupte Provinz? Russische Beamte im 19. Jahrhundert, Frankfurt, New York: Campus Verlag.

Simis K. M. (1982) USSR - the Corrupt Society: The Secret World of Soviet Capitalism, New York: Simon and Schuster.

Tregubowa E. (2006) Die Mutanten des Kreml: Mein Leben in Putins Reich, Berlin: Tropen Verlag.

Wolf S., Graeff P. (eds.) (2018) Korruptionsbekämpfung vermitteln, Springer VS: Wiesbaden. 